\title{
Austrian system squeezes out young clinical researchers
}

\begin{abstract}
Munich. Clinical researchers in Austria do not have enough time to meet the requirements for tenure because they are asked to perform too many other academic tasks. That conclusion is based upon a survey of the medical faculty at Innsbruck University and supports long-standing complaints against the country's habilitation (tenure) system.
\end{abstract}

Clinical researchers, who include those working in molecular biology but not necessarily with human subjects, reported that the need to carry out administrative, teaching and patient functions leaves them with an average of only five hours a week in the laboratory. That is not enough time to complete the work needed to generate the number of publications required to move up the academic ladder. Although the Research Minister, Erhard Busek, is sympathetic to the problem, the federal and state governments disagree on the best way to spend what little money is available to relieve some of the pressure on these scientists.

The survey of nearly 450 ( 60 per cent) of the medical faculty was commissioned two years ago by the Tyrolean Chamber of Physicians in an attempt by Busek to obtain data to support complaints from researchers. Organized by Kurt Grünewald, chairman of the chamber's Mittelbau (all faculty except for full professors), it is the first survey in Europe to address the working conditions of untenured research workers.

In Austria, $\mathrm{PhDs}$ or medically qualified doctors wishing to take up a university research career must first complete a twoyear contract, during which time they must publish a proportion, usually around 50 per cent, of the minimum required for tenure. They can then apply for a five-year contract (or four years in the case of basic biosciences). In these five years they must complete, and in practice usually exceed, a publishing requirement that rewards quality as well as quantity (articles in more important journals are valued more highly than those in lesserknown journals), as well as demonstrating overall expertise in their field.

Researchers get only one chance. Failure at the end of either contract terminates any possibility of a research career.

The survey quantifies the differences in the way in which basic scientists and those in clinical research spend their time. It shows that basic scientists spend more time than clinical researchers on administration and teaching - six and nine hours compared with four and four hours, respectively and four times as much time in the laboratory -20 versus 5 hours. The shortfall in research hours in clinical disciplines is made up at weekends; scientists spend around 10 hours outside their normal working day catching up. But clinical researchers have to spend an average of 33 hours per week on patient care. But even this time competes with overtime clinical work which averages 24 hours a week.

Gerald Zernig, a university assistant who has a hearing this month for tenure in pharmacology at Innsbruck University, has worked in both basic and clinical disciplines. "It surprises me that scientists in clinical disciplines are able to survive and make it under this pressure," he says.

Grünewald says that more staff are needed to do routine patient work and administration, a move that would free tenure-track researchers to spend more time at the laboratory bench. But it is not just a question of money. Whereas most university departments are funded almost exclusively by the federal government, two-thirds of the funding for clinical departments come from the local states, such as Tyrol. "We have two bosses," says Grünewald. "Our work is split between the university and the state clinic. Pressure would be eased if there were a clear separation between the two."

The problem is not unique to Innsbruck. Helmut Tritthart, dean of the medical faculty at Austria's second largest university, in Graz, has long campaigned for greater investment in university clinical research. "In California, clinicians can spend 50 per cent of their time on research." If the situation does not improve, he says, clinical researchers will become a dying breed.

Busek defends the amount of money his government spends on research, pointing out that it has grown by 10 per cent in the past three years. But he says his immediate priority is to expand funding in Vienna, where a new 2,000-bed hospital will open soon. He hopes that the staffing levels in clinical research departments can be increased within the next three or four years. The federal government and the state governments of Tyrol and Steiermark are also negotiating how to divide the bill for clinical research; neither side wants to take on prime responsibility.

Two options remain if the delay is extended. The faculty could report formally to Busek that it is unable to carry out its duties. The ministry would then be obliged to investigate and propose legislative action to reverse the situation. Or the faculty could work to rule, doing their research and treating emergency patients only. Grünewald says that either action would be used only as a last resort because of its impact.

Alison Abbott
IN BRIEF

Las Vegas. American Telephone and Telegraph (AT\&T) announced last week that it will end its 43-year role as contractor for the federal government's Sandia National Laboratory in Albuquerque, New Mexico. The decision gives the US Department of Energy 16 months to find another company that is willing to manage the government's primary facility for maintaining its stockpile of nuclear weapons.

AT\&T has managed Sandia on a nonprofit basis since 1949 following a request by President Harry Truman to help the country defend itself during the early days of the Cold War. Its current five-year contract expires on 30 September 1993.

Both organizations have changed since that time. Once a monopoly providing telephone service nationwide, AT\&T is now an international competitor for global markets in communications, computing products and services. Sandia has also taken on a broader role, encompassing research on energy and environmental topics. Mary Manning

Munich. The 10-day strike by the German public service sector cut sharply into attendance at Analytica, the world's largest laboratory and process instrumentation show held in Munich last week. The challenge of closed airports and intermittent train and subway service resulted in a crowd of only 36,000 at the four-day show.

Foreign visitors were especially inconvenienced by the work stoppages, which ended when the government finally agreed to meet the compromise wage demand, only slightly higher than its original offer, proposed by the unions.

Alison Abbott

Washington. A $\$ 7.5$ million funding guarantee from a private foundation will allow the Columbus telescope project to rebound from last year's loss of one of its partners. Peter Strittmatter, director of the University of Arizona's Steward Observatory, which is leading the effort to build the binocular telescope on Arizona's Mount Graham, says that other partners are expected to join. But the guarantee from Research Corporation, an Arizonabased non-profit research foundation, will allow the project to resume immediately. Eventually Research Corporation. plans to have about a $\$ 2$ million share in the $\$ 40$ million project; it plans to distribute the corresponding viewing time to researchers at small universities and others who would otherwise not have access to a state-ofthe-art telescope.

Ohio State University, one of the project's three original partners (along with Italy's Arcetri Astrophysical Observatory), pulled out last year, leaving the telescope at least $\$ 15$ million short (see Nature 353, 97; 1991). But subsequent negotiations (prompted by the threat of a lawsuit) have brought the parties to a reconciliation of sorts.

Christopher Anderson 